\title{
Analysis of the glacial geomorphological characteristics of the last glacial in the Tianger area, Tien Shan, and their paleoclimate implications
}

\author{
NIE Zhenyu, PAN Renyi, LI Chuanchuan, ZHANG Mei, LIU Gengnian \\ College of Urban and Environmental Sciences, Peking University, Beijing, China \\ E-mail: liugn@pku.edu.cn
}

\begin{abstract}
The Tianger area in the Tien Shan preserves many glacial landforms to which several methods of estimating ancient equilibrium-line altitudes (ELAs) can be applied. Thus it provides the opportunity to compare different methods and evaluate the correlation between the methods and their errors. This comparison provides guidance in the application of these methods in other mid-latitude alpine glaciated areas. In this paper we calculate characteristic ratios relating to the ELAs, including accumulation-area ratio (AAR), toe-headwall altitude ratio (THAR), terminus-summit altitude method (TSAM) and Höfer value, and their correlations with each other and the geomorphological characteristics. The AAR of a glacier is small when the slope of the bedrock beneath it is small and the area is large, and the AAR of a glacier with such characteristics is better correlated with its THAR, TSAM and Höfer value. Paleoclimate information derived from these characteristic ratios relating to ELAs is discussed. The glaciers and the glacial climate of the early and middle stage of the last glacial are more continental than those of the Last Glacial Maximum (LGM). Compared with those of the LGM on the Qinghai-Tibetan Plateau and surrounding mountains, the ELA characteristics of the early and middle stage of the last glacial in the Tianger area show more continental features.
\end{abstract}

KEYWORDS: climate change, glacial geomorphology, glacier fluctuations, paleoclimate

\section{INTRODUCTION}

The equilibrium line of a glacier is an important indicator of climate conditions. Reconstruction of equilibrium-line altitude (ELAs) using geomorphologic methods is an important part of paleoclimate reconstruction. With the development in recent years of geomorphologic evolution theory and GIS spatial analysis methods, geomorphologic analysis based on digital elevation models (DEMs) provides a brand new approach to the study of Earth surface processes and also a new approach to studying the glacial equilibrium line (Benn and Lehmkuhl, 2000; Benn and others, 2005; Owen and Benn, 2005; Deng and others, 2006).

In research of glacial landforms, the area and ELA are important in paleoclimate reconstruction. High-resolution DEM and satellite images are useful in the identification of glacial landforms, and the development of GIS software facilitates the extraction of geomorphological information (Liu and others, 2005; Deng and others, 2006; Hong and others, 2007; Zhang and others, 2010) such as the area of glaciation and the ELA.

Based on earlier work and DEM data, in this paper we re-extract, integrate and analyze the data relating to the glacial extent and the ELAs in the Tianger area of the Tien Shan using GIS software. Fieldwork and previous studies show that there were two distinct glacier advances during the last glacial. The earlier advance appears in marine isotope stage 3 (MIS3) and MIS4, while the later advance appears in MIS2. The glacial extent of the earlier advance is larger than that of the later advance. The paleoclimate information contained in this phenomenon calls for further study.

\section{STUDY AREA}

The study area is located in the central Tien Shan (42.5$43.5^{\circ} \mathrm{N}, 86.25-87.83^{\circ} \mathrm{E}$ ), Xingjiang, western China (Fig. 1). Tianger peak is the highest peak in the study area, with an altitude of $4486 \mathrm{~m}$ a.s.l. The mountain ridges in this area range from 4100 to $4300 \mathrm{~m}$ a.s.l. Modern glaciers develop in this area and the major types are cirque glaciers, hanging glaciers and small valley glaciers. The modern ELA is $\sim 4000-4100 \mathrm{~m}$ a.s.I. (Li and others, 2003, 2007; Yang and others, 2005).

Glacial landforms left behind by ancient glaciers are abundant and provide ideal materials for study. The study of ancient glacial remains is an important part of reconstructing the Quaternary environment (Huang, 1944; Ding, 1947a,b; Zheng and Wang, 1983; Zheng and Zhang, 1983; Cui and others, 1998; Zhou and others, 2002; Shi and others, 2006). The abundant ancient glacial landforms and sedimentary phenomena in the Tien Shan area have attracted the attention of numerous researchers.

Recently, glacial geomorphological and Quaternary environmental studies have developed rapidly in two directions. One is the development of chronological techniques, such as optically stimulated luminescence (OSL), terrestrial cosmogenic nuclide (TCN), ${ }^{14} \mathrm{C}$ accelerator mass spectrometry $\left({ }^{14} \mathrm{C}-\mathrm{AMS}\right)$ and electron spin resonance (ESR) (Yi and others, 1998, 2001, 2004; Zhao and others, 2002, 2006, 2009; Owen and others, 2005; Kong and others, 2009; Li and others, 2011). The chronological study in the headwater of Ürümqi river is among the most thorough and detailed works (Table 1). The other is the application of DEM data and GIS software. The former make it possible to establish a reliable and high-resolution chronological 


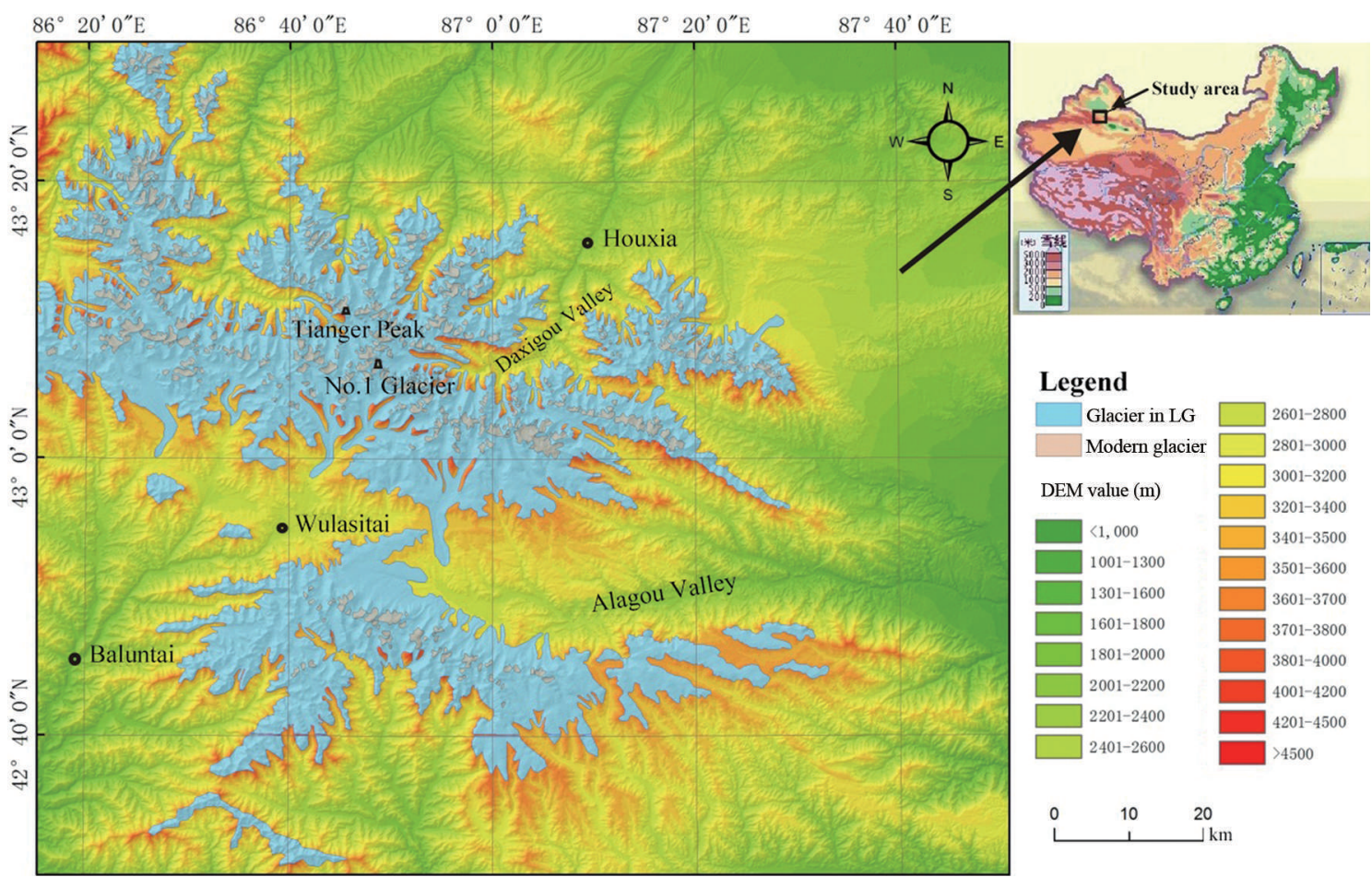

Fig. 1. Geomorphological map of the study area.

sequence of glaciation and the latter provides the opportunity to quantitatively and numerically extract information on paleoenvironment reconstruction from glacial landforms and sediments (Hock and Jensen, 1999; Benn and Lehmkuhl, 2000; Wu and others, 2001; Deng and others, 2006).

\section{METHOD}

The data source is the distribution map of glaciers of the last glacial in the Tianger area, Tien Shan, compiled by the Tianshan Glaciological Station, Chinese Academy of Sciences (Yang and others, 1993). This map is based on a 1:50000 topographic map, and the glacial extents and landforms are acquired through aerial photographs (taken in 1964) and field surveys. The map shows the extents of modern glaciers and ancient glaciers during the last glacial and the position and altitude of ancient equilibrium lines, mountain divides, rivers and lakes in the area $42.5-43.5^{\circ} \mathrm{N}$, $86.25-87.83^{\circ} \mathrm{E}$. The scale of the map is 1:200 000 .

The map is digitized and matched with the DEM map using ArcGIS software and then the information contained in the source map is transcribed into the DEM map. Subsequently, the following data are extracted: elevation, slope, aspect, distribution range of modern glaciers (before 1964), distribution range of glaciers during the last glacial, ridgeline, ELA, glacier terminus altitude and other data on the Tianger area. Combining the interpretation of the aerial photographs and satellite images and fieldwork in parts of the area, corrections are made to decrease the errors. The DEM map of the study area is then drawn. Macroscopic geomorphologic features and distributive patterns of glaciers during the last glacial in the Tianger area are acquired after analysis of the DEM map using ArcGIS software. With application of methods of calculating the ELAs of ancient

Table 1. Datings and glaciations in the headwater of Ürümqi river (after Yi and others, 1998, 2001, 2004; Zhao and others, 2006; Kong and others, 2009; Li and others, 2011)

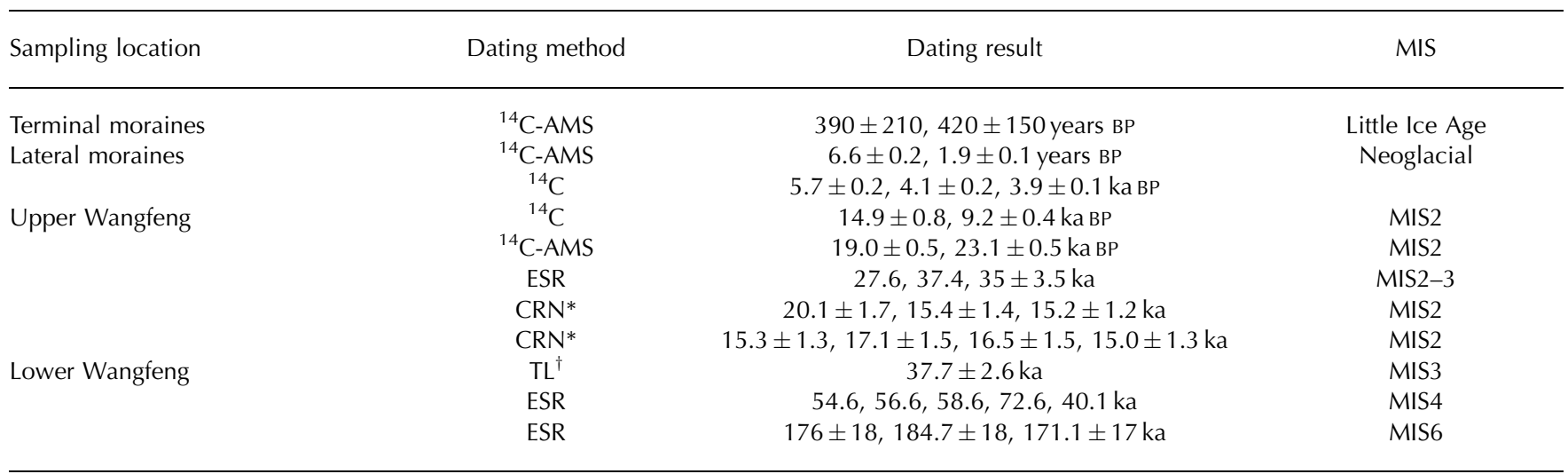

${ }^{*}$ Cosmogenic radionuclide; ${ }^{\dagger}$ thermoluminescence. 


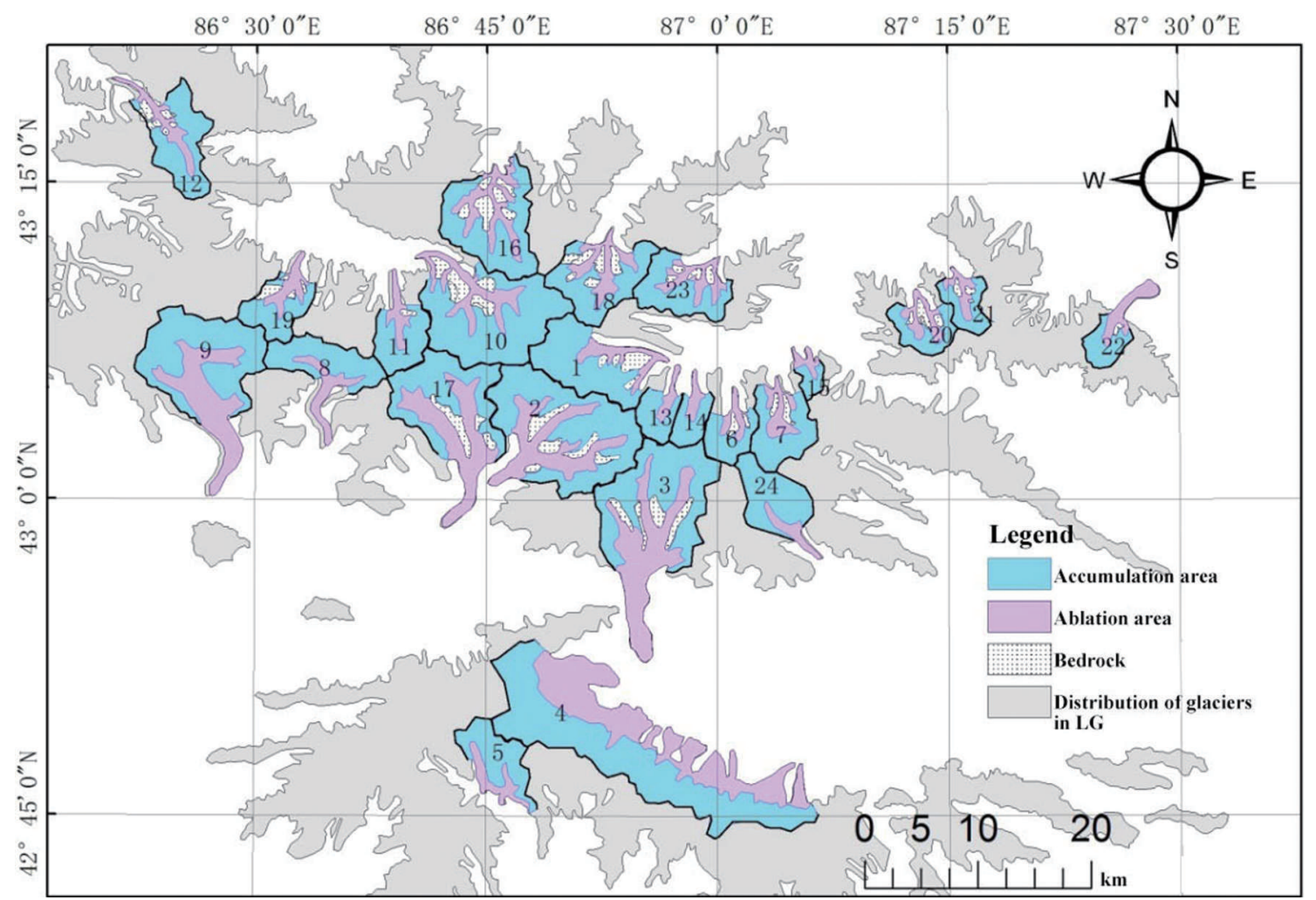

Fig. 2. Schematic diagram of the serial numbers of selected glaciers during the last glacial.

glaciers, the distributive patterns and the characteristic ratios relating to the ELAs of this area are discussed. The DEM data are from the Advanced Spaceborne Thermal Emission and Reflection Radiometer (ASTER) global DEM (GDEM) (30 m resolution), and the World Geodetic System 1984 ellipsoidal elevation (WGS84) coordinate system is adopted.

The accumulation area, ablation area and headwall altitude of selected glaciers are calculated using GIS software. Consulting the known data of equilibrium-line and glacier terminus altitudes, the accumulation-area ratio (AAR), toe-headwall altitude ratio (THAR), terminus-summit altitude method (TSAM) and Höfer method are employed to analyze the characteristics of the glacial equilibrium line.

The availability of initial data for estimating ancient ELAs varies in different areas. In a specific area, the available initial data can be used in some methods, but other methods may be invalid due to the lack of key inputs. Therefore, comparison between different methods is important, especially in areas with better availability of initial data, i.e. where more complete inputs can be acquired. The correlations between different ratios relating to ELA acquired through different methods demonstrate which methods can be substituted. Better correlation means the corresponding methods are interchangeable. This result can be applied to other areas with similar geomorphological features.

\section{RESULTS}

\section{Analyses of the distributive patterns during the last glacial in the Tianger area}

Geomorphologic analyses based on DEM

According to the base map (1964), the total area of modern glaciers in the study area is $325.03 \mathrm{~km}^{2}$ and that of glaciers during the last glacial is $3614.03 \mathrm{~km}^{2}$. The latter area is 11.12 times the former.

\section{Analyses of the ELA characteristics of typical drainage} basins during the last glacial

The glacial valleys in the study area are divided according to drainage basins, and 24 typical glacial valleys are chosen from which to extract geomorphologic factors (Fig. 2; Table 2). In these selected drainage basins, 16 are on the north slope of Tianger peak, six on the south slope, one on the north slope of Alagou valley and one on the south slope. The total area of the 24 glaciers is $1214.73 \mathrm{~km}^{2}$ and accounts for $33.61 \%$ of the total glaciated area during the last glacial. The total accumulation area is $824.62 \mathrm{~km}^{2}$ and the total ablation area is $390.12 \mathrm{~km}^{2}$. The ELAs during the last glacial are in the range $3400-3650 \mathrm{~m}$, and the mean altitude is $3507 \mathrm{~m}$.

\section{Correlation analyses}

Pearson's simple correlation coefficient is employed to analyze the characteristic ratios of the equilibrium line of 24 glaciers. The correlation values between the AAR and the THAR, TSAM and Höfer method are 0.625, 0.571 and 0.666 , respectively, which indicate medium correlation, and the correlation value between the AAR and Höfer is the highest. As the Höfer method adopts the mean height of the watershed at the back of a glacier for calculation, the value of which is distributed in a large area and susceptible to the size of the glacier, partial correlation analysis is applied to the Höfer method. The result shows that the correlation between the Höfer value and the AAR decreases slightly to 0.637 after removing the influence of glacier area. This indicates that glacier area interferes with the Höfer method and the AAR but the effect is weak. There is a relatively strong correlation between the Höfer value and the AAR. 
Table 2. Distributive characteristics of the 24 selected glaciers of the last glacial in the study area

\begin{tabular}{|c|c|c|c|c|c|c|c|c|c|c|c|c|c|}
\hline \multirow[t]{2}{*}{ No. of glacier and location } & \multirow{2}{*}{$\begin{array}{l}\text { Total } \\
\text { area } \\
\mathrm{km}^{2}\end{array}$} & \multirow{2}{*}{$\begin{array}{c}\text { Accumu- } \\
\text { lation } \\
\text { area } \\
\mathrm{km}^{2}\end{array}$} & \multirow{2}{*}{$\begin{array}{c}\text { Ablation } \\
\text { area } \\
\\
\mathrm{km}^{2}\end{array}$} & \multirow{2}{*}{$\begin{array}{c}\text { ELA } \\
\text { m }\end{array}$} & \multirow{2}{*}{$\begin{array}{l}\text { Mean } \\
\text { elevation } \\
\text { of head- } \\
\text { wall } \\
\text { m }\end{array}$} & \multirow{2}{*}{$\begin{array}{c}\text { Altitude } \\
\text { of highest } \\
\text { peak on } \\
\text { headwall } \\
\text { m }\end{array}$} & \multirow{2}{*}{$\begin{array}{c}\text { Mean } \\
\text { elevation of } \\
\text { watershed } \\
\text { at back of } \\
\text { glacier } \\
\text { m }\end{array}$} & \multirow{2}{*}{$\begin{array}{c}\text { Altitude of } \\
\text { terminus } \\
\text { m }\end{array}$} & \multirow{2}{*}{ AAR } & \multirow[t]{2}{*}{ THAR } & \multirow[t]{2}{*}{ TSAM } & \multirow[t]{2}{*}{ Höfer } & \multirow[t]{2}{*}{ Aspect } \\
\hline & & & & & & & & & & & & & \\
\hline 2 Heixiong valley & 105.30 & 71.47 & 33.83 & 3600 & 4188 & 4340 & 4040 & 3091 & 0.68 & 0.54 & 0.59 & 0.46 & SW \\
\hline 3 Arexigongjin valley & 104.62 & 58.59 & 46.03 & 3650 & 4185 & 4320 & 3974 & 2895 & 0.56 & 0.41 & 0.47 & 0.30 & $\mathrm{~S}$ \\
\hline 4 Dundesala valley & 184.54 & 4111.13 & 73.41 & 3500 & 4189 & 4425 & 4037 & 2722 & 0.60 & 0.47 & 0.54 & 0.41 & NE \\
\hline 5 Southwest of Dundesala valley & 33.97 & 725.33 & 8.63 & 3650 & 4235 & 4440 & 4122 & 3117 & 0.75 & 0.52 & 0.60 & 0.47 & S \\
\hline 6 One headwater of Ürümqi river & 19.65 & 14.65 & 4.99 & 3500 & 4268 & 4350 & 4135 & 3146 & 0.75 & 0.68 & 0.71 & 0.64 & $\mathrm{~N}$ \\
\hline 7 One headwater of Ürümqi river & 34.48 & 25.91 & 8.57 & 3500 & 4205 & 4405 & 4054 & 2854 & 0.75 & 0.52 & 0.58 & 0.46 & $\mathrm{~N}$ \\
\hline 9 Huoerhatiguole & 88.90 & 61.09 & 27.81 & 3600 & 4215 & 4400 & 3989 & 2957 & 0.69 & 0.49 & 0.55 & 0.38 & $\mathrm{~S}$ \\
\hline 10 Wulutesayi & 91.89 & 73.19 & 18.70 & 3500 & 4319 & 4500 & 4106 & 2817 & 0.80 & 0.55 & 0.59 & 0.47 & NW \\
\hline 11 West of Wulutesayi & 28.88 & 22.12 & 6.77 & 3450 & 4099 & 4310 & 3994 & 2902 & 0.77 & 0.54 & 0.61 & 0.50 & $\mathrm{~N}$ \\
\hline 12 Northwest of the study area & 42.46 & 27.14 & 15.32 & 3400 & 4211 & 4500 & 4010 & 2816 & 0.64 & 0.58 & 0.65 & 0.51 & NW \\
\hline 13 One headwater of Ürümqi river & 16.92 & 13.14 & 3.78 & 3500 & 4098 & 4150 & 4017 & 2855 & 0.78 & 0.48 & 0.50 & 0.44 & NE \\
\hline 14 One headwater of Ürümqi river & 15.56 & 11.74 & 3.82 & 3500 & 4200 & 4290 & 4042 & 2793 & 0.75 & 0.50 & 0.53 & 0.43 & $\mathrm{~N}$ \\
\hline 15 One headwater of Ürümqi river & 8.72 & 5.48 & 3.23 & 3400 & 3873 & 4005 & 3752 & 2703 & 0.63 & 0.40 & 0.46 & 0.34 & $\mathrm{~N}$ \\
\hline 16 North of Tianger peak & 63.91 & 45.16 & 18.75 & 3400 & 4167 & 4510 & 3947 & 2480 & 0.71 & 0.45 & 0.55 & 0.37 & $\mathrm{~N}$ \\
\hline 17 West of Heixiong valley & 79.21 & 43.73 & 35.47 & 3620 & 4183 & 4340 & 4025 & 2880 & 0.55 & 0.43 & 0.49 & 0.35 & $\mathrm{~S}$ \\
\hline 18 North of No. 1 glacier & 44.98 & 31.03 & 13.94 & 3500 & 4179 & 4280 & 4001 & 2840 & 0.69 & 0.51 & 0.54 & 0.43 & $\mathrm{~N}$ \\
\hline 19 North of No. 8 and No. 9 & 27.55 & 19.30 & 8.24 & 3480 & 4154 & 4245 & 4000 & 2780 & 0.70 & 0.49 & 0.52 & 0.43 & NE \\
\hline 20 South of Haxiong valley & 20.74 & 13.34 & 7.40 & 3450 & 3994 & 4110 & 3846 & 2800 & 0.64 & 0.46 & 0.50 & 0.38 & NW \\
\hline 21 Upstream of Haxiong valley & 17.19 & 11.56 & 5.63 & 3420 & 4003 & 4200 & 3845 & 2800 & 0.67 & 0.48 & 0.56 & 0.41 & $\mathrm{~N}$ \\
\hline 22 Northeast of study area & 19.44 & 11.38 & 8.06 & 3400 & 4042 & 4150 & 3877 & 2840 & 0.59 & 0.53 & 0.57 & 0.46 & NE \\
\hline $\begin{array}{l}23 \text { North of headwater of Ürümqi } \\
\text { river }\end{array}$ & 37.91 & 27.35 & 10.56 & 3500 & 4171 & 4260 & 3998 & 2770 & 0.72 & 0.48 & 0.51 & 0.41 & $\mathrm{NE}$ \\
\hline
\end{tabular}

Comparison between the north and south slopes

Aspect strongly influences the water and heat conditions under which the glaciers develop. Twenty-two glaciers around Tianger peak were chosen to be compared, of which 16 are on the north slope and six are on the south slope (Fig. 2; Table 3). The total area of glaciers on the north slope is $579.29 \mathrm{~km}^{2}$ and on the south slope is $452.26 \mathrm{~km}^{2}$, which makes them comparable. The ELA of glaciers on the south slope is $132 \mathrm{~m}$ higher than that on the north slope. The averages of mean altitude of the highest points on the headwall, altitude of the highest peak and mean altitude of the watershed at the back of the cirque are all higher on the north slope; the differentials are 46,35 and $32 \mathrm{~m}$, respectively. The characteristic ratios calculated using four geomorphologic methods are slightly higher on the north slope, with a maximum differential of 0.04 (Table 3). Correlation analyses are applied to the four characteristic ratios, and the correlation value is 0.991 which indicates a strong correlation.

Correlation analyses are applied to the characteristic ratios of the north and south slopes, respectively (Table 4). The correlations between the AAR and the THAR, TSAM and Höfer value are very strong on the south slope, with correlation coefficients of $>9.3$. Partial correlation analysis is applied to the Höfer method to remove the influence of glacier area, and the correlation coefficient decreases to 0.846 , which still indicates a strong correlation. The correlations on the north slope are weaker than those on the south slope, with correlation coefficients ranging from 0.46 to 0.55 , which indicates medium to low correlations.

Table 3. Characteristics of glaciers of the last glacial on the north and south slopes of Tianger peak

\begin{tabular}{|c|c|c|c|c|c|c|c|c|c|c|c|c|}
\hline Location & Area & $\begin{array}{l}\text { Accumu- } \\
\text { lation area }\end{array}$ & $\begin{array}{l}\text { Ablation } \\
\text { area }\end{array}$ & ELA & $\begin{array}{l}\text { Mean } \\
\text { elevation of } \\
\text { headwall }\end{array}$ & $\begin{array}{c}\text { Altitude of } \\
\text { highest peak } \\
\text { on headwall }\end{array}$ & $\begin{array}{l}\text { Mean elevation } \\
\text { of watershed at } \\
\text { back of glacier }\end{array}$ & $\begin{array}{l}\text { Altitude of } \\
\text { terminus }\end{array}$ & AAR & THAR & TSAM & Höfer \\
\hline & $\mathrm{km}^{2}$ & $\mathrm{~km}^{2}$ & $\mathrm{~km}^{2}$ & $\mathrm{~m}$ & $\mathrm{~m}$ & $\mathrm{~m}$ & $\mathrm{~m}$ & $\mathrm{~m}$ & & & & \\
\hline North slope & 34.08 & 24.91 & 9.16 & 3471 & 4147 & 4303 & 3994 & 2851 & 0.72 & 0.53 & 0.57 & 0.46 \\
\hline South slope & 75.38 & 49.13 & 26.25 & 3603 & 4193 & 4338 & 4026 & 3034 & 0.68 & 0.52 & 0.57 & 0.44 \\
\hline
\end{tabular}


Table 4.. Correlation analysis of the ELA characteristics of the last glacial on the north and south slopes of Tianger peak

\begin{tabular}{lll}
\hline South slope (binary variables correlation analysis - Pearson) & AAR & North slope (binary variables correlation analysis - Pearson) \\
\hline THAR & 0.948 & THAR \\
TSAM & 0.939 & TSAM \\
Höfer & 0.933 & Höfer \\
Partial correlation analysis (removing the influence of area) & & Partial correlation analysis (removing the influence of area) \\
Höfer & 0.846 & Höfer \\
& & \\
\hline
\end{tabular}

Table 5. Characteristics of glaciers of two groups divided according to the median of area

\begin{tabular}{|c|c|c|c|c|c|c|c|c|c|c|c|c|}
\hline \multirow[t]{2}{*}{ Group } & Area & $\begin{array}{l}\text { Accumu- } \\
\text { lation area }\end{array}$ & $\begin{array}{l}\text { Ablation } \\
\text { area }\end{array}$ & ELA & $\begin{array}{c}\text { Mean elevation } \\
\text { of headwall }\end{array}$ & $\begin{array}{l}\text { Altitude of } \\
\text { highest peak } \\
\text { on headwall }\end{array}$ & $\begin{array}{l}\text { Mean elevation } \\
\text { of watershed at } \\
\text { back of glacier }\end{array}$ & $\begin{array}{l}\text { Altitude of } \\
\text { terminus }\end{array}$ & AAR & THAR & TSAM & Höfer \\
\hline & $\mathrm{km}^{2}$ & $\mathrm{~km}^{2}$ & $\mathrm{~km}^{2}$ & $\mathrm{~m}$ & $\mathrm{~m}$ & $\mathrm{~m}$ & $\mathrm{~m}$ & $\mathrm{~m}$ & & & & \\
\hline $\mathrm{A}\left(>36.62 \mathrm{~km}^{2}\right)$ & 78.03 & 51.71 & 26.32 & 3527 & 4196 & 4377 & 4022 & 2860 & 0.68 & 0.50 & 0.56 & 0.43 \\
\hline $\mathrm{B}\left(<36.62 \mathrm{~km}^{2}\right)$ & 23.20 & 17.01 & 6.19 & 3488 & 4121 & 4257 & 3985 & 2908 & 0.72 & 0.53 & 0.57 & 0.47 \\
\hline
\end{tabular}

\section{Comparison between large and small glaciers}

The 24 glaciers are divided into two groups by the median of area to discuss whether the glacier area influences the characteristics of the equilibrium line (Table 5). The median area of the 24 glaciers is $36.62 \mathrm{~km}^{2}$. Glaciers with an area $>36.62 \mathrm{~km}^{2}$ are classed as group A, while those $<36.62 \mathrm{~km}^{2}$ are classed as group $B$. The averages of the main features of the glaciers are shown in Table 5.

The average area of glaciers in group A is 3.36 times larger than that of group B, and the four equilibrium-line characteristics of glaciers in group A are all slightly lower than those of group B. Correlation analyses are applied to the four characteristics of groups $A$ and $B$, and the correlation is 0.991 which indicates a very strong correlation. In the two groups of glaciers divided by the median of area, the four equilibrium-line characteristics are correlated strongly and positively with area.

The correlation analysis results of the equilibrium characteristics of the two groups of glaciers are shown in Table 6. The correlations of the characteristics of the two groups of glaciers are both median. Partial correlation analysis is applied to the Höfer method to remove the influence of glacier area, and the correlation coefficients between the AAR and the Höfer value in the two groups both decrease. That of group A decreases by 0.058 , while that of group $\mathrm{B}$ decreases by 0.132 . The decrease in the correlation coefficient of group B is more than that of group A, which indicates the correlation between the AAR and the Höfer value is more susceptible to glacier area in smaller glaciers.

\section{Analyses of the distributive features of glaciers in typical areas during the last glacial}

Headwater of Ürümqi river

The geomorphologic map of the headwater of Ürümqi river is shown in Figure 3. According to earlier work, the glaciations in the headwater of Ürümqi river are divided into Little Ice Age, neoglacial, late stage of last glacial (upper Wangfeng till) and early/middle stage of last glacial (lower Wangfeng till), as shown in Figure 3. The distribution of glaciers in this map basically coincides with the result of earlier work.

Six glacier samples are chosen in the headwater of Ürümqi river (Table 7), with a total area of $149.02 \mathrm{~km}^{2}$. The dominant aspects are east and north and the ELAs range from 3400 to $3500 \mathrm{~m}$, with an average of $3483 \mathrm{~m}$. The AARs range from 0.63 to 0.78 , with an average of 0.74 . The THARs range from 0.48 to 0.68 , with an average of 0.53 . The TSAMs range from 0.46 to 0.71 , with an average of 0.57 . The Höfer values range from 0.34 to 0.64 , with an average of 0.48 .

Correlation analyses are applied to the characteristic ratios of the equilibrium lines of the six glaciers in the headwater. The correlations between the AAR and the THAR, TSAM and Höfer value are 0.562, 0.474 and 0.573, respectively, which all indicate medium to low correlation. The correlation coefficient decreases to 0.460 after

Table 6. Correlation analysis of the ELA characteristics of two groups divided according to the median of area

\begin{tabular}{lll}
\hline Group A (binary variables correlation analysis - Pearson) & AAR & Group B (binary variables correlation analysis - Pearson) \\
\hline THAR & 0.645 & THAR \\
TSAM & 0.561 & TSAM \\
Höfer & 0.639 & Höfer \\
Partial correlation analysis (removing the influence of area) & & Partial correlation analysis (removing the influence of area) \\
Höfer & 0.5810 & Höfer \\
& &
\end{tabular}




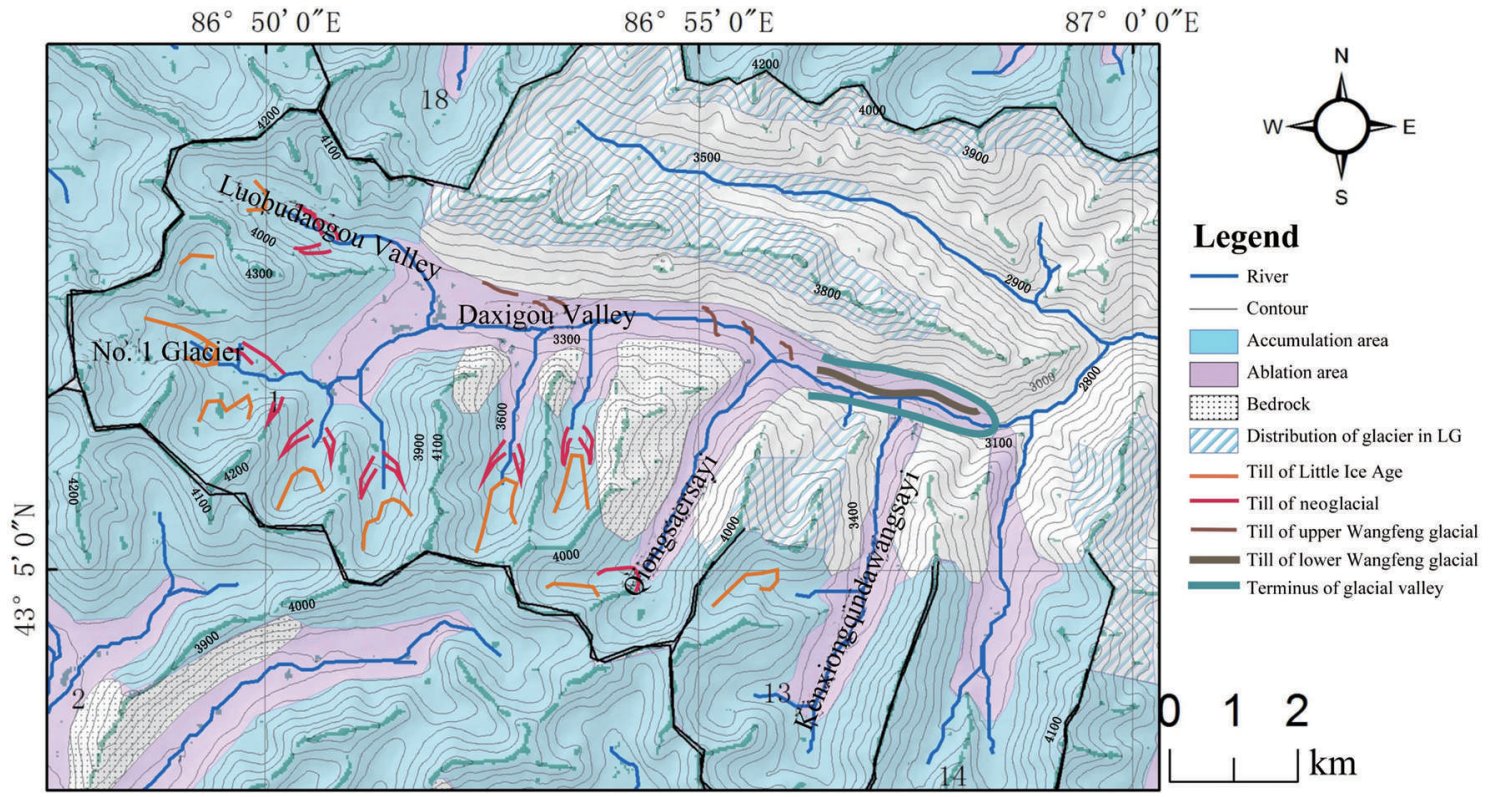

Fig. 3. Geomorphological map of the source area of Ürümqi river.

removing the effect of area. The decrease range of 0.113 indicates that area has a relatively strong influence over the correlation between these two ratios in the headwater.

\section{Headwater of Alagou valley}

According to the fieldwork, the termini of glaciers reached an altitude of $2800 \mathrm{~m}$ when they advanced to their maximum range in the Alagou valley. The locations of tills of the Little Ice Age, neoglacial, late stage of the last glacial and early/middle stage of the last glacial are inferred. The distribution map of ancient glaciers since the last glacial in the Alagou valley is acquired (Fig. 4) after consulting the data in Figure 1 and the DEM.

Arexigongjin and Dundesala glaciers in the headwater of the Alagou valley are chosen for analysis (Table 8). Arexigongjin glacier is located on the south slope of Tianger peak, with an ELA of $3650 \mathrm{~m}$, which is $150 \mathrm{~m}$ higher than that of Dundesala glacier on the north slope of Alagou peak. The AARs of the two glaciers are 0.56 and 0.60 , which is relatively low considering the average of the whole study area. The other three characteristic ratios are also relatively low.

Following comparison of two typical regions in the study area, it is found that the four equilibrium-line characteristic ratios of glaciers on the south slope are all lower than those on the north slope and this coincides with the general feature of the influence of aspect over glacial equilibrium line, as mentioned above.

\section{DISCUSSION \\ Spatial variation of ELA ratios}

In the glaciated area during the last glacial in the study area, the AARs of glaciers on the south slope are lower and are much better correlated with the THAR, TSAM and Höfer value than those on the north slope. In the comparison of two groups of glaciers divided by median area, the correlations between the AAR and Höfer value of smaller glaciers are more susceptible to area than those of larger glaciers. Therefore, the AARs of glaciers with a gentler slope and larger area are lower and are better correlated with the THAR, TSAM and Höfer value. In the Tianger area, the south slope has more matching conditions as mentioned above, while in the Alagou area the north slope is gentler than the south slope. The No. 4 glacier representing the north slope is larger than the No. 5 glacier representing the south slope, and the AAR of the former is lower. Meanwhile, No. 3 and No. 4 glaciers representing the Alagou area are both larger, with gentler slope, and their AARs are notably lower than the

Table 7. Distributive characteristics of the selected glaciers of the last glacial in the source area of Ürümqi river

\begin{tabular}{|c|c|c|c|c|c|c|c|c|c|c|}
\hline \multirow[t]{2}{*}{$\begin{array}{l}\text { No. of glacier } \\
\text { (this paper) }\end{array}$} & Total area & $\begin{array}{c}\text { Accumulation } \\
\text { area }\end{array}$ & $\begin{array}{l}\text { Ablation } \\
\text { area }\end{array}$ & ELA & $\begin{array}{l}\text { Altitude of } \\
\text { terminus }\end{array}$ & AAR & THAR & TSAM & Höfer & Aspect \\
\hline & $\mathrm{km}^{2}$ & $\mathrm{~km}^{2}$ & $\mathrm{~km}^{2}$ & $\mathrm{~m}$ & $\mathrm{~m}$ & & & & & \\
\hline 1 & 53.70 & 40.91 & 12.80 & 3500 & 2970 & 0.76 & 0.58 & 0.64 & 0.55 & $\mathrm{E}$ \\
\hline 6 & 19.65 & 14.65 & 4.99 & 3500 & 3146 & 0.75 & 0.68 & 0.71 & 0.64 & $\mathrm{~N}$ \\
\hline 7 & 34.48 & 25.91 & 8.57 & 3500 & 2854 & 0.75 & 0.52 & 0.58 & 0.46 & $\mathrm{~N}$ \\
\hline 13 & 16.92 & 13.14 & 3.78 & 3500 & 2855 & 0.78 & 0.48 & 0.50 & 0.44 & NE \\
\hline 14 & 15.56 & 11.74 & 3.82 & 3500 & 2793 & 0.75 & 0.50 & 0.53 & 0.43 & $\mathrm{~N}$ \\
\hline 15 & 8.72 & 5.48 & 3.23 & 3400 & 2703 & 0.63 & 0.40 & 0.46 & 0.34 & $\mathrm{~N}$ \\
\hline Average & 24.84 & 18.64 & 6.20 & 3483 & 2887 & 0.74 & 0.53 & 0.57 & 0.48 & \\
\hline Total & 149.02 & 111.83 & 37.20 & & & & & & & \\
\hline
\end{tabular}




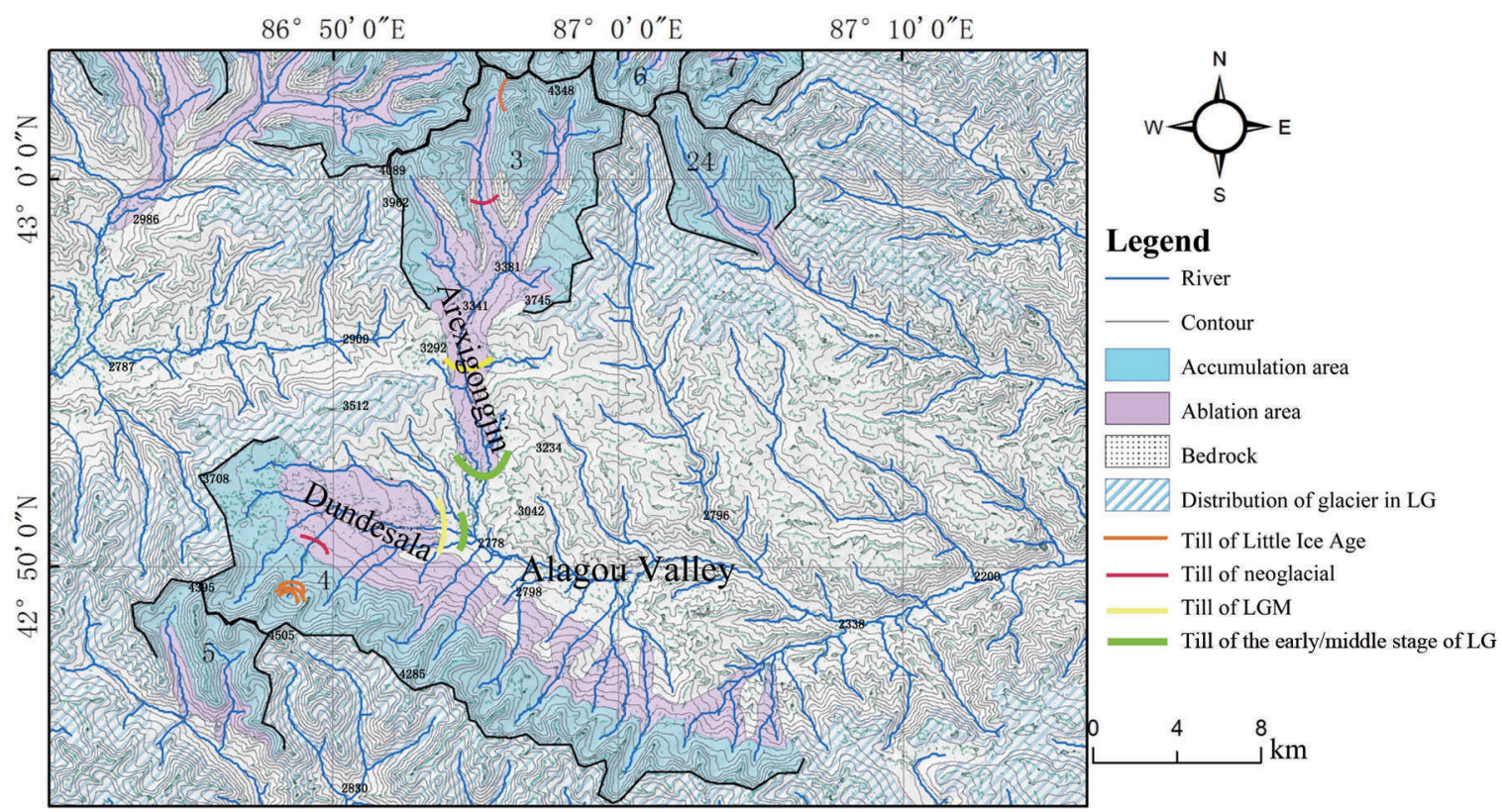

Fig. 4. Distribution map of ancient glaciers of the last glacial in Alagou valley.

average of the whole study area. Compared with those of the headwater of Ürümqi river, the slopes of this area are gentler.

\section{Climatic implications of the variation of glacial equilibrium-line characteristic ratios in the headwater of Ürümqi river}

According to the observation data from 1959 to 2002, the average ELA of No. 1 glacier is $4053 \mathrm{~m}$ (Li and others, 2003; Yang and others, 2005).

Zhang (1981) calculated that the ELA during the upper Wangfeng glacial was $3630 \mathrm{~m}$ using an AAR of 0.6. Xu and others (2010) calculated the ancient ELA during the LGM in the headwater and found ELAs of 3615 and $3675 \mathrm{~m}$ using AARs of 0.55-0.65.

The distributive range of the No. 1 sample glacier in this paper covers the modern No. 1-No. 9 glaciers in the headwater area, which is the area that has been studied most thoroughly in terms of Quaternary glaciers. Its area is $53.70 \mathrm{~km}^{2}$ and the ELA is $\sim 3500 \mathrm{~m}$, which is $553 \mathrm{~m}$ lower than the modern ELA. The AAR is 0.76 , which is higher than the value of 0.55 or 0.65 adopted by Xu and others (2010) for the calculation of ancient ELA during the LGM. The AAR is directly proportional to the accumulation area: the larger the accumulation area, the higher the AAR value. Meanwhile, it can be found from the sequence of tills in the headwater that the distributive range of glaciers during the last glacial reaches its maximum in the early/middle stage rather than in the LGM, i.e. in the late stage of the last glacial. The data adopted in this paper are of the maximum range during the last glacial, i.e. the distributive range of glaciers during the early/middle stage of the last glacial. Therefore, through comparison of these two values mentioned above, it can be inferred that the AARs are higher and the accumulation areas are larger in the early/middle stage of the last glacial than in the LGM.

Higher AARs indicate continental characteristics of glaciers. Shi and others (2006) proposed that MIS4, or the early stage of the last glacial, was a dry and cold period in western China, which was slightly warmer and more humid than the LGM in MIS2. Consulting different data, researchers come to different conclusions when calculating the difference in temperature between the LGM and modern time at different locations on the Qinghai-Tibetan Plateau, and the average is $\sim 7^{\circ} \mathrm{C}$. Xu and others (2010) proposed that, in the headwater of Ürümqi river, the temperature from June to August was $5.42-6.30^{\circ} \mathrm{C}$ lower during the LGM than it is today and that the precipitation was only $30 \%$ of the modern value. Compared with maritime glaciers, continental glaciers often show drier and colder features, i.e. lower temperature and less precipitation. The average AAR of glaciers in the early/middle stage of the last glacial is 0.76 , and that in the LGM ranges from 0.55 to 0.65 . The former is more continental. The modern alpine glaciers can be classified into three climatic categories: extreme continental, subcontinental and maritime. The modern glaciers in the headwater of Ürümqi river are in the subcontinental category. However, they may be in the extreme continental category in the early/middle stage of the last glacial.

Table 8. Distributive characteristics of the selected glaciers of the last glacial in Alagou valley

\begin{tabular}{|c|c|c|c|c|c|c|c|c|c|c|}
\hline \multirow[t]{2}{*}{ No. } & \multirow[t]{2}{*}{ Glacier } & \multirow{2}{*}{$\begin{array}{l}\text { Area } \\
\mathrm{km}^{2}\end{array}$} & \multirow{2}{*}{$\begin{array}{c}\text { Accumu- } \\
\text { lation area } \\
\mathrm{km}^{2}\end{array}$} & \multirow{2}{*}{$\begin{array}{c}\text { Ablation area } \\
\mathrm{km}^{2}\end{array}$} & \multirow{2}{*}{$\begin{array}{l}\text { ELA } \\
\text { m }\end{array}$} & \multirow[t]{2}{*}{ AAR } & \multirow[t]{2}{*}{ THAR } & \multirow[t]{2}{*}{ TSAM } & \multirow[t]{2}{*}{ Höfer } & \multirow[t]{2}{*}{ Aspect } \\
\hline & & & & & & & & & & \\
\hline 3 & Arexigongjin & 104.62 & 58.59 & 46.03 & 3650 & 0.56 & 0.41 & 0.47 & 0.30 & S \\
\hline 4 & Dundesala & 184.54 & 111.13 & 73.41 & 3500 & 0.60 & 0.47 & 0.54 & 0.41 & NE \\
\hline
\end{tabular}


The formation and evolution of the Himalaya and the Qinghai-Tibetan Plateau influence atmospheric circulation and climate change in Asia, or even the globe. This region has always been a focus of research. Owen and others (2005) reviewed 21 glaciers in the Himalaya and QinghaiTibetan Plateau, and the results show that the ancient ELAs during the LGM range from 3000 to $5920 \mathrm{~m}$ in this region, while the modern ELAs range from 3750 to $6200 \mathrm{~m}$. The ELAs in different locations within this region differ considerably because there are two climate systems influencing the development of glaciers in this region, namely the westerlies in the mid-latitude and the south Asian summer monsoon, and the topographic factor also plays an important role. In studies of ancient ELAs during the LGM in this region, most researchers choose AAR and THAR for comparison and the AAR value is always chosen around 0.6, while the THAR value is always chosen in the range $0.4-0.5$. Liu and others (2011) proposed that an AAR of 0.35 is more suitable for the distribution of glaciers during the last glacial in the study of glaciers on Peiku Gangri, northwest of Shisha Pangma peak. This value is much lower than the AAR of 0.53 corresponding to the modern ELA, and the probable causes are the effects of aspect and topography, which make the accumulation area smaller than other alpine glaciers in mid-latitudes.

The comparison in this paper between the equilibriumline characteristic ratios during the LGM on the Himalaya and Qinghai-Tibetan Plateau and those during the early/ middle stage of the last glacial in the Tianger area shows that the average AAR of the latter is 0.7 , which is higher than the most frequent AAR of 0.6 of the former, while the average THAR of the latter is 0.51 , which is slightly higher than that of the former. Assuming that the two studies are comparable in terms of method, it can be inferred that glaciers during the early/middle stage of the last glacial in the Tianger area are more continental than those during the LGM on the Himalaya and Qinghai-Tibetan Plateau.

\section{CONCLUSION}

1. The ELA of glaciers during the last glacial in the headwater of Ürümqi river is $\sim 3500 \mathrm{~m}$, which is $553 \mathrm{~m}$ lower than the modern ELA. The AAR is 0.76 , which is higher than that during the LGM. It can be inferred that the AARs are higher and the accumulation areas are larger in the early/middle stage of the last glacial than in the LGM. Compared with the modern subcontinental glaciers in this region, those in the early/middle stage of the last glacial are more like extreme continental glaciers.

2. In the comparison between the equilibrium-line characteristic ratios during the LGM on the Himalaya and Qinghai-Tibetan Plateau and those during the early/ middle stage of the last glacial in the Tianger area, assuming the two sets of data are comparable in terms of method, it can be inferred that glaciers during the early/ middle stage of the last glacial in the Tianger area are more continental than those during the LGM on the Himalaya and Qinghai-Tibetan Plateau.

3. Slope and area are related to the equilibrium-line characteristic ratios of glaciers. The AAR values of glaciers with gentler slopes and larger areas are lower and are better correlated with the THAR, TSAM and Höfer value.

\section{ACKNOWLEDGEMENTS}

This project was supported by the National Natural Science Foundation of China (grant Nos. 40971002, 41230743). We acknowledge fieldwork support provided by the Tianshan Glaciological Station, Chinese Academy of Sciences. Jon Harbor, Arjen Stroeven, Li Yingkui and Li Yanan participated in the fieldwork. We thank the anonymous reviewers and the scientific editor for constructive suggestions which improved the manuscript.

\section{REFERENCES}

Benn DI and Lehmkuhl F (2000) Mass balance and equilibrium-line altitudes of glaciers in high mountain environments. Quat. Int., 65-66, 15-29 (doi: 10.1016/S1040-6182(99)00034-8)

Benn DI, Owen LA, Osmaston HA, Seltzer GO, Porter SC and Mark B (2005) Reconstruction of equilibrium-line altitudes for tropical and sub-tropical glaciers. Quat. Int., 138-139, 8-21 (doi: 10.1016/j.quaint.2005.02.003)

Cui Z, Xiong H, Liu G, Zhu C and Yi C (1998) Geomorphological processes and sedimentary features of cryosphere in the middle Tianshan Mountains, China. Hebei Science and Technology Press, Shijiazhuang [in Chinese]

Deng Y, Xie Z and Li L (2006) The establish of snowline field in southern Tibet based on GIS and its spatial distributive characteristics. Yunnan Geogr. Environ. Res., 03, 10-14 [in Chinese]

Ding X (1947a) Expedition notes of the topography of Yili, Xinjiang. Acta Geogr. Sinica, 14(3-4), 1-10 [in Chinese]

Ding X (1947b) Notes of the survey around Dihua, Xinjiang. Acta Geogr. Sinica, 14(2), 30-35 [in Chinese]

Hock R and Jensen $H$ (1999) Application of kriging interpolation for glacier mass balance computations. Geogr. Ann. A, 81(4), 611-619

Hong S, Shen X, Jing F and Du Z (2007) An analysis of the tectonic geomorphological characteristics of the Altai Mountains based on SRTM-DEM. Remote Sens. Land Resour., 3, 62-66 [in Chinese]

Huang TK (1944) Pleistocene moraine and non-moraine deposits in Taqlaq area, north of Aqsu, Sinkiang. Bull. Geol. Soc. China, 24(1-2), 125-146 [in Chinese]

Kong P, Fink D, Na C and Huang F (2009) Late Quaternary glaciation of the Tianshan, Central Asia, using cosmogenic ${ }^{10} \mathrm{Be}$ surface exposure dating. Quat. Res., 72(2), 229-233 (doi: 10.1016/j.yqres.2009.06.002)

Li Y, Liu G, Kong P, Harbor J, Chen Y and Caffee M (2011) Cosmogenic nuclide constraints on glacial chronology in the source area of the Ürümqi River, Tian Shan, China. J. Quat. Sci., 26(3), 297-304 (doi: 10.1002/jqs.1454)

Li Z, Han T, Jing Z, Yang H and Jiao K (2003) A summary of 40-year observed variation facts of climate and Glacier No. 1 at headwater of Ürümqi River, Tianshan, China. J. Glaciol. Geocryol., 25(2), 117-123 [in Chinese with English summary]

Li Z and 6 others (2007) Response of melting ice to climate change in the Glacier No. 1 at the headwaters of Ürümqi river, Tianshan Mountain. J. Glaciol. Geocryol., 29(3), 333-342

Liu G and 6 others (2011) Glacial landform chronology and environment reconstruction of Peiku Gangri, Himalayas. J. Glaciol. Geocryol., 33(5), 959-970 [in Chinese]

Liu S, Wang T, Zhang H, Cheng S, Sun Y and Lei G (2005) Application of DEM in earth surface process study. Earth Sci. Front., 12(1), 303-309

Owen LA and Benn DI (2005) Equilibrium-line altitudes of the Last Glacial Maximum for the Himalaya and Tibet: an assessment and evaluation of results. Quat. Int., 138-139, 55-78 (doi: 10.1016/j.quaint.2005.02.006)

Owen LA and 6 others (2005) Climatic and topographic controls on the style and timing of Late Quaternary glaciation throughout Tibet and the Himalaya defined by ${ }^{10} \mathrm{Be}$ cosmogenic radio- 
nuclide surface exposure dating. Quat. Sci. Rev., 24(12-13), 1391-1411 (doi: 10.1016/j.quascirev.2004.10.014)

Shi Y, Cui Z and Su Z (2006) Quaternary glaciers and environmental changes. Hebei Science and Technology Press, Shijiazhuang [in Chinese]

Wu L, Liu Y, Zhang J, Ma X, Wei Z and Tian Y (2001) Geographic information system: principles, method and application. Beijing Science Press, Beijing [in Chinese]

Xu X, Wang L and Yang J (2010) Last Glacial Maximum climate inferences from integrated reconstruction of glacier equilibriumline altitude for the head of the Ürümqi river, Tianshan Mountains. Quat. Int., 218(1-2), 3-12 (doi: 10.1016/j.quaint. 2009.11.027)

Yang H, Ren B, Li N and Gu P (1993) Distribution map of glaciers of the Last Glacial in Tianger Area, Tianshan. In Annual Report of Tianshan Glaciological Station, Vol. 12. Journal of Glaciology and Geocryology [in Chinese]

Yang H, Li Z, Ye B, Jiao K and Zhao Z (2005) Study on mass balance and process of Glacier No. 1 at the headwaters of the Ürümqi River in the past 44 years. Arid Land Geogr., 28(1), 76-80 [in Chinese with English summary]

Yi C, Liu K and Cui Z (1998) AMS dating on glacial till at the source area of the Ürümqi river valley in the Tien Shan Mountains and its implications. Chinese Sci. Bull., 43(6), 655-656 [in Chinese]

Yi C, Jiao K, Liu K, Li L and Ye Y (2001) ESR dating of moraines and the Last Glacial sequence of the source area of Ürümqi River in Tianshan. J. Glaciol. Geocryol., 23(4), 389-393 [in Chinese]

Yi C, Liu K, Cui Z, Jiao K, Yao T and He Y (2004) AMS radiocarbon dating of late Quaternary glacial landforms, source of the Ürümqi River, Tien Shan - a pilot study of ${ }^{14} \mathrm{C}$ dating on inorganic carbon. Quat. Int., 121(1), 99-107 (doi: 10.1016/ j.quaint.2004.01.026)

Zhang R, Fang H, Zhao F and Zeng F (2010) Remote sensing survey of existing snowlines in the past 30 years in Qinghai-Tibet Plateau. Remote Sens. Land Resour., 22(suppl.), 59-63 [in Chinese with English summary]

Zhang Z (1981) Changes of snowline at the head of Ürümqi river, Tian Shan. J. Glaciol. Cryoped., 3(Suppl.), 106-113 [in Chinese with English summary]

Zhao J, Zhou S, Cui J, Jiao K, Ye Y and Xu L (2002) Study on the ESR dating of moraines in the source area Ürümqi River. J. Glaciol. Geocryol., 24(6), 737-743 [in Chinese]

Zhao J, Zhou S, He Y, Ye Y and Liu S (2006) ESR dating of glacial tills and glaciations in the Ürümqi River headwaters, Tianshan Mountains, China. Quat. Int., 144(1), 61-67 (doi: 10.1016/ j.quaint.2005.05.013)

Zhao J, Wang J and Shangguan D (2009) Quaternary glacial sedimentary sequence in the Tumur River drainage in Tianshan and its preliminary chronology. J. Glaciol. Geocryol., 31(4), 628-633 [in Chinese]

Zheng B and Wang C (1983) Discussion on Quaternary glaciation in the Bogda region, Tian Shan. J. Glaciol. Geocryol., 5(3), 123-132 [in Chinese with English summary]

Zheng B and Zhang Z (1983) Glacier changes during the neoglaciation in Bogda area, Tianshan and the source area of Ürümqi River. J. Glaciol. Geocryol., 5(3), 133-141 [in Chinese]

Zhou S, Jiao K, Zhao J, Zhang S, Cui J and Xu L (2002) Geomorphology of the Ürümqi River Valley and the uplift of the Tianshan Mountains in Quaternary. Sci. China D, 45(11), 961-968 